\title{
Effective Environmental Factors on Milk Composition, Rennet Coagulation Time and Urea Content of in Anatolian Buffaloes Milk of Ilıkpınar Village Hatay Province
}

\author{
Özel Şekerden ${ }^{1, *}$ and Yahya Kemal Avşar ${ }^{2}$ \\ ${ }^{1}$ Mustafa Kemal Univ. Fac. of Agric. Dept. of Anim. Sci., Antakya, Turkey \\ ${ }^{2}$ Mustafa Kemal Univ. Fac. of Agric. Dept. of Food Engineering, Antakya, Turkey
}

\begin{abstract}
The objectives of this study were to investigate determining environmental factors on composition, renneting time, urea concentration, acidity, density and $\mathrm{pH}$ of Anatolian Buffaloes milk. As a total of 115 milk samples from 53 cows that were calved in the period of 2004 and 2005 years in 8 units of Ilıkpınar Village were collected in morning milkings in June, September, December and March. The cows were at their lactation days $30 \pm 15,60 \pm 15,90 \pm 15$, $120 \pm 15,150 \pm 15,180 \pm 15,210 \pm 15,240 \pm 15$ and $270 \pm 15$. The milk samples were analysed for total dry matter, fat, protein, ash, density, $\mathrm{pH}$, acidity, renneting time and urea content. Rennet coagulation time, urea, protein and fat contents were determined using Berridge, photometric, formal titration and Gerber methods, respectively. Data were classified as

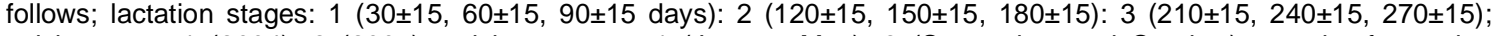
calving year: 1 (2004), 2 (2005); calving season: 1 (January-May), 2 (September and October); month of samples collection: 1 (June), 2 (September), 3 (December), 4 (March); lactation order: 1 and 2:1, 3 and 4: 2, 5 and 6: 3. The effects of environmental factors of each variable were investigated separately and analysed using analysis of variance. Production mount in all the characteristics; calving year and lactation stage in most of the characteristics; lactation order on fat and protein contents; unit and calving season in some of the characteristics were found to be effective significantly. SPSS program was used in the statistical procedures.
\end{abstract}

Keywords: Buffalo, milk properties, variation sources.

\section{INTRODUCTION}

Feeding [1], lactation stage [2,3], calving season and lactation order [4-6] have significant effects on milk yield and fat, casein, protein, total dry matter (TDM). Milk coagulation properties [rennet coagulation time, firming time and firmness of clot] are very important to cheese production and can be affected by genotype [7, 8] season, lactation order, lactation stage and feeding [9].

Lactation number does not have a significant effect on milk coagulation ability [7], whereas season has such an effect owing to the reduction in urea content of milk [10]. Feeding level is effective on urea content of milk. Milk coagulation properties differ significantly from one unit to another. The differences are due most likely to feeding and management factors [7].

Povinelli et al. [8] found that breed, herd and lactation stage had a significant effect on milk coagulation ability unlike the urea content. $\mathrm{pH}$ has a negative effect on milk coagulation ability [11].

Roy et al. [12] reported that a significant reduction occurred in milk urea concentration as the lactation

*Address correspondence to this author at the Mustafa Kemal Üniversitesi, Ziraat Fakültesi, Zootekni Bölümü, Antakya, Turkey;

E-mail: sekerden@mku.edu.tr number increased. However, lactation stage did not have significant effects on urea and protein concentrations of milk.

The objectives of this study were to investigate effective environmental factors on milk composition, rennet coagulation time, urea concentration, titratable acidity, density and pH of Anatolian Buffaloes' milk.

\section{MATERIAL AND METHODS}

The material of the study consisted of 115 milk samples from 53 Anatolian buffalo cows of Ilıkpınar Village of Kırıkhan District of Hatay Province in 8 units that they were calved in 2004 and 2005. Milk samples were collected from the morning milking in June, September, December and March from the cows on lactation days $30 \pm 15,60 \pm 15,90 \pm 15,120 \pm 15,150 \pm 15$, $180 \pm 15,210 \pm 15,240 \pm 15$ and $270 \pm 15$. From the beginning of June of 2004, milk samples were collected of all the buffalo cows in morning milking monthly at milk control days of June, September, December and March. The samples were analysed for total dry matter, fat, protein, ash contents, $\mathrm{pH}$, density, rennetting time and milk urea content. Protein and fat contents were determined by formol titration [13] and Gerber methods [14], respectively. Rennet coagulation time was determined by recording time from the addition of enzyme to milk to the appearance of first clot using Berridge method [15]. 
Milk urea content determined with diacetyl monoxime using photometric method, as described in Merck handbook [16]. Data were classified as follows; $30 \pm 15$., $60 \pm 15,90 \pm 15$ days: $1^{\text {st }}$; $120 \pm 15,150 \pm 15$, $180 \pm 15: 2^{\text {nd }} \cdot ; 210 \pm 15,240 \pm 15,270 \pm 15: 3^{\text {rd }}$ lactation stages. 2004: $1^{\text {st }}, 2005: 2^{\text {nd }}$ calving years; January-May period: 1st, September and October Months: $2^{\text {nd }}$ calving seasons; June: $1^{\text {st }}$, September: $2^{\text {nd }}$, December: $3^{\text {rd }}$, March: $4^{\text {th }}$ production months (samples collection months); $1^{\text {st }}$ and $2^{\text {nd }}: 1$ st, $3^{\text {rd }}$ and $4^{\text {th }}: 2^{\text {nd }}, 5^{\text {th }}$ and $6^{\text {th }}: 3^{\text {rd }}$ lactation order groups. The effect of environmental factors on each characteristic were analysed separately using variance analysing technique. The means and correlation coefficients of each character were calculated. SPSS program was used in the statistical procedures.

\section{RESULTS AND DISCUSSION}

Variance analysis are given in Tables $\mathbf{1}$ and 2 . As can be seen in Table 1, morning milk yield was affected by unit, production month (PM) and calving season (CS); daily milk yield was affected by unit, PM, lactation stage (LS) and calving year (CY) significantly. Differences in daily milk yield between $C Y$ can be explained by differences in feeding level during, year to year and unit to unit. As opposed to the literature [5], the effects of lactation order (LO) on morning and daily milk yields were found not significant in this study (Table 1). As is clear from Table 2, PM, LS and CY were influential on TDM content. The effects of PM and $\mathrm{CY}$ can be explained by feeding conditions since a pasture-based feeding in the Village was commonly employed. The literature also supported that PM [6] and LS [1] effects on TDS were significant. However, the effect of lactation order effect on TDM content was found insignificant on Anatolian buffaloes in an earlier study [2]. PM, LS, CY and LO were influential on fat content significantly. The effects of PM and CY on fat can be explained by feeding level. The literature supported the significant effects of PM [2, 10] and LS [1] on fat content (Table 2).

Table 1: Variance Analysis for Morning and Daily Milk Yields, Rennet Coagulation Time, pH, Density and Titratable Acidity

\begin{tabular}{|c|c|c|c|c|c|c|c|}
\hline \multirow{2}{*}{$\begin{array}{l}\text { Variation } \\
\text { Source }\end{array}$} & \multirow[t]{2}{*}{ f.d. } & \multicolumn{6}{|c|}{$F$} \\
\hline & & $\begin{array}{l}\text { Morning } \\
\text { milkyield }\end{array}$ & $\begin{array}{l}\text { Daily milk } \\
\text { Yield }\end{array}$ & $\begin{array}{c}\text { Rennet } \\
\text { coagulation }\end{array}$ & $\mathrm{pH}$ & Density & $\begin{array}{c}\text { Titratable } \\
\text { acidity }\end{array}$ \\
\hline Unit & 7 & $11.400^{* * *}$ & $12.149^{* * *}$ & 1.193 & $2.841^{*}$ & 1.508 & $5.497^{* * *}$ \\
\hline Prod. Month & 3 & $7.275^{\star * *}$ & $8.531^{* * *}$ & $12.931^{* * *}$ & $3.246^{*}$ & $22.553^{\star * *}$ & $4.898^{\star *}$ \\
\hline Calving season & 1 & $6.516^{*}$ & 0.474 & $4.563^{*}$ & 0.066 & 0.085 & 1.758 \\
\hline Lactation stage & 2 & 0.067 & $5.424^{* *}$ & $10.049^{* * *}$ & $7.076^{* *}$ & $3.534^{*}$ & $9.687^{* * *}$ \\
\hline Calving year & 1 & 1.371 & $5.295^{*}$ & $13.169^{\star \star \star}$ & $2.918^{*}$ & $35.519^{* \star *}$ & $12.733^{\star *}$ \\
\hline Lactation order & 2 & 1.915 & 1.360 & 0.972 & 1.699 & 0.740 & 1.185 \\
\hline Total N & & 115 & 115 & 115 & 115 & 107 & 115 \\
\hline
\end{tabular}

${ }^{*} \mathrm{P}<0.05,{ }^{* *} \mathrm{P}<0.01,{ }^{* * *} \mathrm{P}<0.001$.

Table 2: Variance Analysis for TDM, Fat, Ash, Protein and Urea Contents

\begin{tabular}{|c|c|c|c|c|c|c|}
\hline \multirow{2}{*}{$\begin{array}{c}\text { Variation } \\
\text { source }\end{array}$} & \multirow[t]{2}{*}{ f.d. } & \multicolumn{5}{|c|}{$\mathbf{F}$} \\
\hline & & TDM & Fat & Ash & Protein & Urea \\
\hline Unit & 7 & 0.997 & 0.644 & 0.781 & 1.225 & $1.831^{*}$ \\
\hline Prod.Month & 3 & $6.017^{\star *}$ & $3.025^{\star}$ & $19.797^{* * *}$ & $9.191^{* * *}$ & $6.081^{* *}$ \\
\hline Calving season & 1 & 0.002 & 0.842 & 0.003 & $5.425^{\star}$ & 1.293 \\
\hline Lactation stage & 2 & $3.611^{*}$ & $10.758^{\star * *}$ & $4.610^{*}$ & $3.869^{*}$ & 0.689 \\
\hline Calving year & 1 & $38.739^{\star \star *}$ & $46.880^{\star \star \star *}$ & $14.403^{\star \star *}$ & $110.153^{\star \star *}$ & 1.110 \\
\hline Lactation order & 2 & 0.356 & $3.377^{*}$ & 0.805 & $3.538^{*}$ & 1.223 \\
\hline Total N & & 109 & 109 & 107 & 109 & 100 \\
\hline
\end{tabular}

${ }^{\star} \mathrm{P}<0.05,{ }^{* \star} \mathrm{P}<0.01,{ }^{* \star \star} \mathrm{P}<0.001$ 
Ash content was also affected by PM, LS and CY (Table 2). PM, CS, LS, CY and LO were found to be effective on protein content significantly. Alteration in milk fat and protein contents are related to feeding level and climatic conditions. Literature also confirms that PM $[2,10]$ and CS [6] are influential on protein content of milk. The significant effect of LO on milk protein content was also reported [5]. The milk yield varies due to LS and there are negative relationship between milk yield with fat and protein contents of milk. Protein and fat contents were highest at the beginning and end of lactation, and lowest during peak lactation associated with milk milk yield [4] (Table 2). Roy et al. [12] reported that LS did not have a significant effect on milk protein concentration in Murrah buffaloes.

The $\mathrm{pH}$ of milk samples were affected by unit, $\mathrm{PM}$, LS and CY; the density was similarly affected by PM, LS and CY significantly. PM, CS, LO and CY were effective significantly on rennet coagulation time (Table 1). Literature reports that milk coagulation properties can be affected by production season and feeding level and LS [7, 9]; coagulation properties are well related to alteration in fat and protein contents at the beginning and end of lactation. However, the significant effect of LO on coagulation properties are reported by some researchers [9] whereas findings supporting our results were reported by the others [7]. In spite of literature indicating that milk coagulation properties vary from one unit to another significantly, this was found insignificant in our study since feeding was based mainly on village pasture, and supplement fodders were almost the same in every unit (Table 1). Titratable acidity was affected by unit, PM, LS, CY at significant levels (Table 1). Similarly, urea content of milk was affected by unit and PM significantly (Table 2). It can be suggested that urea concentration was affected by only feeding level since both sample collection months and unit factors are related to feeding levels. It is reported that production season and feeding level [10] are effective on milk urea concentration. It was also reported that milk urea concentration is affected by LO significantly, but LS does not have an important effect on milk urea concentration [12] as was found in our study (Table 2 ).

\section{REFERENCES}

[1] Waldner DN, Stokes SR, Jordan ER, Looper ML. Managing milk composition: Normal sources of variation. http://www.ansi.okstate.edu/exten/dairy/wf-4016.html, 06.06.2003.

[2] Şekerden Ö, Tapkı İ, Şahin M. Changing of milk composition in first ten days and along of the lactation in Black Pied cattle. J Atatürk Univ Fac Agric 1999; 30: 37-40.

[3] Şekerden Ö, Tapkı I, Kaya Ş. Changing of milk yield and composition with lactation stage and production season at village conditions of Hatay Province in Anatolian buffaloes. $J$ Atatürk Univ Fac Agric 1999; 30: 161-68.

[4] Patel KS, Majmudar SV, Patel HB, Saiyed LH. Lactation curve for milk fat content in Surti buffaloes. Gujarat Agric Univ Res 1991; 16: 82-83.

[5] Polanski S, Czaka H, Latocha M. The effect of some factors on milk fat and protein percentage of Simmental cows at the Brzozow pedigree farm. Roczniki Naukowe Zootechniki 1992; 19: 55-65.

[6] Şekerden Ö. Effects of calving season and lactation order on milk yield and milk components in simmental cows. Turk $J$ Vet Anim Sci 1999; 23: 79-86.

[7] Ikoneen T. Possibilities of genetic Improvement of milk coagulation properties of dairy cows. Academic Dissetation, Univ. of Helsinki, Dept. Anim. Sci., Publications 2000: No: 49.

[8] Povinelli M, Marcomini D, Zotto RD, Gaiarin G, Gallo L, Carnier $P$, Casandro M. Sources of variation of milk rennetcoagulation ability of five dairy cattle breeds reared in Trento Province. In: Proceedinda of the IX. World Animal Prod. Cong., Porto Alegre 2003.

[9] Kreuzer M, Schulz JP, Fry C, Abel H. Rennet coagulation properties of milk from cows at three stages of lactation supplied with graded levels of an antimicrobial feed supplement. Milchwissenchaft 1996: 51: 243-47.

[10] Foltys V, Pazmova J, Chobotova E, Zatopkova V. Influence of season on composition of bulk milk in relation to its technological processing. In: Proceedings of EAAP 46th Meeting European Association for Animal Production, Prague 1995; p. 210.

[11] Piironen T, Ojala M, Niini T, Syvaoja EL, Setala J. Effects of milk protein genetic variants and lactation stage on renneting properties of bovine milk. In: Proceedings of the $43^{\text {rd }}$ EAAP Meeting, Madrid 1992; pp. 1-12.

[12] Roy B, Mehla RK, Sirohi SK. Influence of milk yield, parity, stage of lactation and body weight on urea and protein concentration in milk Murrah buffaloes. (http://www.ajas.info/ contents/abr/03-9-9 htm), 2004.

[13] James CS. Analytical Chemistry of Foods. Elsevier Publisher, New York 1998.

[14] Kurt A. Guide of Analysis Methods of Milk and Milk's Products. A. Ü. Publ. 1984: No: 18. Lecture book No: 252.

[15] Koçak C, Devrim $\mathrm{H}$. Effect of heat procedure on coagulation ability of goat milks. Gıda 1994; 19: 125-129.

[16] Anonymous. Urea in Milk. 2005. http://photometry.Merck.de/ servlet/PB/menu/1169740_ePRJ-MERCK-EN-pcontent_12/ content.html 